\title{
Effect of Assertiveness Training Program on Psychiatric Mental Health Nurses' Communication Skills and Self-esteem
}

\section{Shaymaa Mahmoud Ahmed Mostafa ${ }^{1}$, Hani Hamed Desouki ${ }^{2}$, Ghada Mohamed Mourad ${ }^{3}$ and Mona Mohamed Barakat ${ }^{4}$}

(1) Assistant lecturer of Psychiatric and Mental Health Nursing, Faculty of Nursing, Beni-suef University, Egypt. (2) Professor of Psychiatric Medicine, Faculty of Medicine, Beni-suef University, Egypt. (3) Professor of Psychiatric and Mental Health Nursing, Ain Shams University, Egypt. (4) Assistant Professor of Psychiatric and Mental Health Nursing, Benha University, Egypt.

\section{Abstract}

Background: Assertiveness is a vital skill in contemporary health care and an essential component for positive and productive working relationships between nursing staff. Aim of the study: This study aimed to assess the effect of an assertiveness training program on psychiatric mental health nurses' communication skills and self-esteem. Research design: A quasiexperimental research design. Setting: The study was carried out at the Psychiatric Mental Health Hospital in Benha City, Kaluobia Governorate. Sample: A convenience sample of (50) psychiatric mental health nurses was included for the conduction of this study. Tools of data collection: The study tools divided into four tools. I: Structured Interview Questionnaire. II: Rosenberg's Global Self-esteem Scale. III: Assertiveness skills scale and IV: Communication Skills Inventory. Results: There was a highly statistically significant differences between total mean scores of selfesteem, assertiveness skills, and communication skills among the studied sample post program implementation compared to preprogram implementation, also there was a highly statistically significant positive correlation between total self-esteem and total assertiveness skills and total communication skills post program implementation. Conclusion: Assertiveness training program have a positive effect on communication skills and self-esteem of psychiatric mental health nurses. Recommendations: Generalization of assertiveness training program for all newly graduated psychiatric nurses in all psychiatric hospitals

Key words: Assertiveness training, Communication skills, Psychiatric mental health nurses, Self-esteem.

\section{Introduction}

Mental health nurses are critical in the delivery of essential health services and are core in strengthening the health system. Bring people-centered care closer to the communities where they are needed most, thereby helping improve health outcomes and the overall cost-effectiveness of services. Mental health nurses operate in an interpersonal context and at the center of this is nurse-patient communication. The ability to establish therapeutic communication with patient is one of the most important skills a nurse can develop. In spite of its importance in all nursing specialties, the therapeutic communication is especially crucial to the success of intervention with patient requiring psychiatric care. If the nurse - patient communication develops well, it can play a large part in sustaining the patient in the face of emotional difficulties, bring about insight and behavior change in them (World Health Organization, 2020). 
Accordingly, communication skills for nurses are essential but may be difficult to master. Communication is the exchange of information between people by sending and receiving it through speaking, writing or by using any other medium. Clear communication means that information is conveyed effectively between people. To be a successful nurse, excellent communication skills are required. Nurses speak to people of varying educational, cultural and social backgrounds and must do so in an effective, caring and professional manner, especially when communicating with patients and their families. The quality of communication in interactions between nurses and patients has a major influence on patient outcomes. This influence can play a very important role in areas such as patient health, education and adherence (Ulutasdemir, 2018).

Also the nurses need to have the assertive communication skills in order to be able to be patients' advocates. Assertiveness enables a person to be honest with him/herself and in relationships with others. Assertiveness is a substantial communication style that enhances successful relationships with patients, families, and colleagues. Assertiveness is an expression of self-esteem. Studies have shown that nurses who have assertive behaviors generally have higher self-worth and are more successful in life (Kanade, 2019).

Assertive persons maintain self-respect and respect for others by assertive behavior which directly expresses one's true, basic feelings, needs, desires, opinions and personal rights in a positive, productive way without denying the rights of others. It enables one to act in her or his interests without undue anxiety. Assertive nurses claim their own rights, make requests of others, can say no to things they do not want, accept praise and can easily verbalizes their feelings. All of these make individuals' lives easier and experience positive responses from others (Shrestha, 2019).

This in turn can decrease anxiety and increase confidence in interpersonal relations. Assertiveness is thought to be a healthy form of behavior. Becoming more assertive can lead to increased respect and recognition as a person and as a nurse. It can get individual more of what his/her want. Assertiveness is considered to be an essential skill for nurses. It is a key attribute for nurses without it true autonomy and personal empowerment cannot be achieved. Assertive behavior demands control over outbursts of anger, crying or other behavior patterns that exhibit lack of professionalism. Assertiveness skills can be seen as "valuable component" for successful professional nursing practice, with which many conflicts in a nursing situation can be successfully ruled out (Sayed, 2018).

The uniqueness of environmental milieu in the psychiatric hospital creates some sort of stress among psychiatric nurses as they come in the first line of contact with patients with different psychiatric disorders. Moreover, patient's symptoms itself may initiate a nurse's maladaptive0+ behavior like aggression as a coping strategy among less experienced nurses to manage the situation. Furthermore, unsupported work environment, the stigma of mental illness, negative attitude toward mental health professionals in Arab countries, and excessive working hours, all are the significant challenges facing psychiatric nurses. These factors may lead to fear, and complaints and without a doubt exhibit negative professional attitudes. So, nurses need to be assertive in the clinical setting 


\section{Effect of Assertiveness Training Program on Psychiatric Mental Health Nurses'}

\section{Communication Skills and Self-esteem}

and confident in the necessary competencies and skills (Abdelaziz et al., 2020).

Previous studies have highlighted the various beneficial effects of enhancing effective communication through assertiveness programs. Precisely, mental health nurses are urgently required to develop and behave assertively to manage lots of challenges they face, such as dealing with unstable/unpredicted patients' symptoms, confronting work overload such as inadequate nurses, inadequate resources, and lack of flexibility of work routine duty, which negatively reflects on their competences to manage work-related stressors. Although, developing assertiveness skills is a complex process and requires time and practice, it is one of the most important skills for nurses in the workplace as it potentiate nurses' sharing opinions with other staff, including those in authority, minimizing their conflicts and being influential in providing quality health care services (Nakamura \& Tanoue, 2017).

Also some studies emphasized the role of assertiveness skills for nurses in the workplace, in reducing their interpersonal stress, building effective team relationships and adding support to one's behavior and giving confidence about one's actions which influence their self-esteem. Thus, assertiveness help nurses to be more competent in the provision of quality patient care, more effective in communicating with others, and using their professional knowledge and skills. Finally, they become more influential in improving the health care delivery system (Mushtaq, 2018).

\section{Significance of the study:}

Evidence based studies have highlighted the beneficial effects of assertiveness training in improving nurses' communication skills, which effectively improve their confidences, self-esteem, personal, and professional growth. Psychiatric nurses are in need to develop assertiveness skills to improve their relationships with the patients, cultivate a safer and secure milieu, and feel a sense of usefulness. Therefore, they have a professional identity. Moreover, nurses who develop assertive communication skills are able to develop and maintain a relationship with their colleagues and supervisors, which leads to better performance (Abdelaziz et al., 2020).

\section{Aim of the study:}

This study aimed to evaluate the effect of an assertiveness training program on psychiatric mental health nurses' communication skills and self-esteem.

\section{Hypothesis:}

The assertiveness training program will have a positive effect on communication skills and self-esteem of psychiatric mental health nurses.

\section{Subject and Methods \\ Design:}

A quasi-experimental design was used in this study.

\section{Setting:}

This study was conducted at the Psychiatric Mental Health Hospital in Benha City, Qalubia Governorate, which is affiliated to General Secretariat of Mental Health in Egypt.

\section{Subject:}

A convenience sample of (50) psychiatric mental health nurses was included for the conduction of the study according to the following equation. All 
nurses received the assertiveness training program.

$$
n=\frac{N \times p(1-p)}{\left.\left[N-1 \times\left(d^{2} \div z^{2}\right)\right]+p(1-p)\right]}
$$

\section{Inclusion criteria:}

- Nurses working in the inpatient psychiatric and mental health departments.

-Nurses who accepted to participate in the study.

\section{Tools for data collection:}

The data was collected through utilizing the following tools:

\section{Tool I: Structured Interview Questionnaire:}

This tool was developed by the researcher based on pertinent literature and guidance of supervisors and includes two parts:

Part one: Socio demographic data: Constructed to describe nurse's age, sex, marital status, level of education, and residence.

Part two: Professional data: Constructed to describe nurse's occupation, years of experiences in psychiatric mental health nursing field, income and attendance of training courses.

\section{Tool II: Rosenberg's Global Self- esteem Scale:}

This scale was developed by Rosenberg (1965) to measure self- esteem. It was translated into Arabic language by Ahmed, (2011). The scale is composed of 10 statements (5 statements are phrased positively and 5 statements are phrased negatively). These statements are rated on a 4-point Likert scale, which are: (4) strongly agree, (3) Agree, (2) disagree, (1) strongly disagree.

According to answers total scoring ranges from 1 to 40, with 40 score indicating the highest possible score. Scoring for negative answers was reversed, i.e., (1) for strongly agree and 4 for strongly disagree, and so on.

\section{Tool III: - Assertiveness skills scale: -}

This scale was originally developed by Wolpe \& Lazarus, (1966). It is composed of 30 items that measure how people behave in the different situations. The scale was translated in to Arabic language and modified by Ghareeb, (1986). The modified scale comprised 25 items, which are answered with yes or no and scored as (1) for yes and (0) for no. Some items are scored in the opposite direction like items number $(2,3,4,6,7,10,12,13,14,15,21,22$, and question 23).

According to answers, total scoring ranges from 0 to 25 , with 25 score indicating the highest possible score. High score is an indicator of high degree of assertiveness, moderate score is an indicator of moderate degree of assertiveness and low score is indicator of low degree of assertiveness.

\section{Tool IV: Communication Skills}

\section{Inventory:}

Communication skills inventory was developed by Ersanlı \& Balci, (1998) to measure communication skills. The scale is composed of 45 items and rated on a- 3 point Likert scale which are; always (3), sometimes (2), rarely (1). Some items are scored in the opposite direction like items number(10,13,16.17,18,20,21,23,24,34,38,4 4). The scale consists of three subdimensions, cognitive, emotional and behavioral communication skills.

The lowest and highest scores from the total communication skills inventory are 45 and 225, respectively. The high scores on the scale indicate that the level of 


\section{Effect of Assertiveness Training Program on Psychiatric Mental Health Nurses' \\ Communication Skills and Self-esteem}

communication skills of the individual is high

\section{Tools validity and reliability:}

The validity of tools had done through five expertise professors of Psychiatric \& Mental Health Nursing Specialties, from different Faculties of Nursing to measure validity of the tools. Test re-test reliability was done, $r=0.92$ for assertiveness scale, $r=$ 0.72 for self-esteem and $\mathrm{r}=0.75$ for communication skills inventory.

\section{Pilot study}

A pilot study was conducted before starting data collection on $10 \%$ of psychiatric mental health nurses (5 nurses) to test the clarity and applicability of the study tools, and identify the time required to fill each tool.

This phase aims at planning for training program through setting educational objectives, preparing the training program and designing the methodology and media.

\section{Ethical considerations:}

Verbal approval was obtained from each participant before collection of any data and after explanation of the study aim in simple and clear manner. Before taking the consent, the subjects were assured about the study confidentiality and anonymity. They informed about their right to withdraw from the study when they like this without giving causes.

\section{Development of the training program:}

The assertiveness training program was developed by the researcher after a thorough review of the literatures. The training program aimed to improving communication skills and self-esteem of the psychiatric mental health nurses. The training program has a set of general and specific objectives for each session. The number of program sessions is about 12 sessions. It divided into introductory session, 2 theoretical sessions and 6 practical sessions, 2 theoretical practical sessions and the last one is summary to the previous sessions. Each session takes about 45- 90 minutes a day. Based on the results obtained from the assessment tools and review of literatures, the program content was developed by the researcher in form of a booklet which was revised and approved by the supervisors, after that the final booklet was distributed for the nurses in the first session.

\section{General objectives of program}

At the end of the assertiveness training program implementation, the psychiatric mental health nurse will able to:

1- Acquire knowledge and skills about assertiveness, communication and self-esteem.

2- Apply assertiveness skills and improve communication skills and self-esteem.

\section{Field work:}

The field work was beginning by data collection (pretest) then implementation of the assertiveness training program for the psychiatric mental health nurses. Data collection of this study was carried out at the Psychiatric Mental Health Hospital in Benha City, Kaluobia Governorate, which is affiliated to General Secretariat of Mental Health in Egypt. The pre-test was collected from each subject every two days/ week 1012 nurse / week. The time needed for each nurse to fulfill the questionnaires was approximately 20-30 min.

The implementation of the assertiveness training program for all subjects of the study 
(50 psychiatric mental health nurse). The subjects of the study were divided into four groups about 12-13 psychiatric mental health nurse in the group. The sessions of the assertiveness training program were carried out during the period (1/ February / 2020 to 30/ July/ 2020. Each session lasted approximately 45-90 minutes. Sessions of the assertiveness training program focused on: (Introduction about aim, objectives and content of the sessions, effective communication skills assertiveness skills, saying N0 assertively, making and responding to request assertively, constructive criticism in the work, expressing unpleasant feelings in work, expressing pleasant feelings as compliment, effective negotiation in work and promoting self-esteem

In the first session, the researcher welcomed the participants and provided detailed information about the number of group members, duration of the program and length of each session, general and specific goals of the program, summary about the content of the program and rules of the group e.g. confidentiality and honesty.

Each session was started with a summary about what was given through the previous session to ensure that the psychiatric mental health nurse understands the program content and the objectives of the new session were mentioned. The researcher used group discussion, role play and brain storming during the session to promote active involvement and enhance interest in the session.

At the end of the session, the researcher provided a summary about the content of the session and a home work sheet distributed to promote transfer and maintenance of the learned skill. Also the researcher told the group about the time of the next session.

\section{Statistical analysis:}

The collected data were organized, computerized, tabulated and analyzed by using the Statistical Package for Social Science (SPSS) version 18. Data analysis was accomplished by the use of number, percentage distribution, mean, standard deviation, and correlation coefficient. Paired t-test was used to compare means within one group and t-test was used to compare two independent means. Chi square test used to compare two of more than two qualitative groups, MC-Nemar test for paired dependent qualitative data and Bivariate Pearson correlation test to test the association between variables. A significant level value was considered when $\mathrm{p}$-value $=<0.05$.

\section{Results:}

Table (1): Illustrates that, less than half (46\%) of the study group aged between 30 and 40 years old with $\mathrm{M} \pm \mathrm{SD}(37.5 \pm 5.8)$. The study shows also, that more than half (52\%) of the study group were female, more than two thirds $(68 \%)$ were married, more than half $(52 \%)$ had diploma and more than three quarter $(78 \%)$ of them were rural inhabitant.

Table (2): Illustrates that, the majority (90\%) of study group worked as nurse, less than half $(46 \%)$ had experience of 10 to 15 years, about three quarters (74\%) had low income which not enough for them and no one received training.

Table (3): Shows that, a highly statistically significant differences between total mean scores changes of self-esteem scale among study group pre and post program implementation at $\mathrm{p}$-value $<0.001$. 


\section{Effect of Assertiveness Training Program on Psychiatric Mental Health Nurses' \\ Communication Skills and Self-esteem}

Table (4): Reveals that, a highly statistically significant differences between total mean score changes of assertiveness skills subscales among study group pre and post program implementation at $p$-value $<0.001$. Also, the table shows a highly statistically significant differences between total mean scores of assertiveness skills scale among study group pre and post program implementation at $\mathrm{p}$-value $<0.001$.

Table (5): Shows that, a highly statistically significant differences between total mean scores changes of communication skills subscales among study group pre and post program implementation at p-value $<0.001$. Also, the table shows a highly statistically significant differences between total mean scores of communication skills among study group pre and post program implementation at $\mathrm{p}$-value $<0.001$.

Table (6): shows that, there was a highly statistically significant positive correlation between total self-esteem and total assertiveness skills and total communication skills post program implementation at $\mathrm{p}$ value $=<0.001$. Also, the result illustrates that a highly statistically significant positive correlation between total assertiveness skills and total communication skills at $\mathrm{p}$ value $=$ $<0$. 001, which indicated increase in selfesteem will associate with increase in assertiveness and communication skills.

Table (1): Socio-demographic data of the studied group $(n=50)$.

\begin{tabular}{|c|c|c|}
\hline Socio-demographic & No & $\%$ \\
\hline \multicolumn{3}{|l|}{ Age (years) } \\
\hline $20-<30$ & 19 & 38.0 \\
\hline $30-<40$ & 23 & 46.0 \\
\hline $40+$ & 8 & 16.0 \\
\hline \multicolumn{3}{|c|}{$M \pm \mathrm{SD} \quad 37.5 \pm 5.8$} \\
\hline \multicolumn{3}{|l|}{ Sex } \\
\hline Male & 24 & 48.0 \\
\hline Female & 26 & 52.0 \\
\hline \multicolumn{3}{|l|}{ Marital status } \\
\hline Single & 16 & 32.0 \\
\hline Married & 34 & 68.0 \\
\hline \multicolumn{3}{|l|}{ Education level } \\
\hline Diploma & 26 & 52.0 \\
\hline Technical institute & 20 & 40.0 \\
\hline Bachelor & 4 & 8.0 \\
\hline \multicolumn{3}{|l|}{ Residence } \\
\hline Rural & 39 & 78.0 \\
\hline Urban & 11 & 22.0 \\
\hline
\end{tabular}


Table (2): Professional data of the studied group ( $n=50)$.

\begin{tabular}{|l|l|l|}
\hline Professional data & No & $\%$ \\
\hline Occupation & 45 & 90.0 \\
\hline Nurse & 5 & 10.0 \\
\hline Supervisor & \multicolumn{2}{l|}{} \\
\hline Years of experience (years) & 3 & 6.0 \\
\hline $2-<5$ years & 14 & 28.0 \\
\hline $5-<10$ years & 23 & 46.0 \\
\hline $10-<15$ years & 10 & 20.0 \\
\hline 15 years and more & \multicolumn{2}{l|}{} \\
\hline Income & 13 & 26.0 \\
\hline Enough & 37 & 74.0 \\
\hline Not enough & \multicolumn{2}{l|}{} \\
\hline Training & 50 & 100.0 \\
\hline No & 0 & 0.0 \\
\hline Yes & \multicolumn{1}{|l}{} \\
\hline
\end{tabular}

Table (3): Comparison between total mean scores changes of self-esteem scale among study group pre and post program implementation $(\mathbf{n = 5 0})$

\begin{tabular}{|c|c|c|l|l|l|}
\hline \multirow{2}{*}{ Scale } & $\begin{array}{c}\text { Study group } \\
\text { Preprogram } \\
(\mathrm{n}=50)\end{array}$ & $\begin{array}{c}\text { Study group } \\
\text { Post program } \\
(\mathrm{n}=50)\end{array}$ & \multicolumn{2}{|c|}{$\begin{array}{c}\text { Paired } \\
\text { difference }\end{array}$} & \multicolumn{2}{|l|}{ Paired sample } \\
\cline { 2 - 6 } & Mean \pm SD & Mean \pm SD & $\begin{array}{l}\text { Mean } \\
\text { difference }\end{array}$ & $\begin{array}{l}\text { T- } \\
\text { Test }\end{array}$ & P-value \\
\hline Self-esteem scale & $13.1 \pm 4.3$ & $23.9 \pm 4.4$ & 10.7 & 12.1 & $<0.001^{* *}$ \\
\hline
\end{tabular}

Table (4): Comparison between total mean scores changes of assertiveness skills scale among study group pre and post program implementation $(n=50)$.

\begin{tabular}{|l|c|c|c|c|l|}
\hline \multicolumn{1}{|c|}{$\begin{array}{c}\text { Assertiveness skills } \\
\text { subscales }\end{array}$} & $\begin{array}{c}\text { Study group } \\
\text { Pre program } \\
(\mathrm{n}=50)\end{array}$ & $\begin{array}{c}\text { Study group } \\
\text { Post program } \\
(\mathrm{n}=50)\end{array}$ & \multicolumn{2}{|c|}{$\begin{array}{c}\text { Paired } \\
\text { difference }\end{array}$} & \multicolumn{2}{|c|}{ Paired sample } \\
\cline { 2 - 6 } & Mean \pm SD & Mean \pm SD & $\begin{array}{l}\text { Mean } \\
\text { difference }\end{array}$ & $\begin{array}{l}\text { T- } \\
\text { Test }\end{array}$ & P-value \\
\hline $\begin{array}{l}\text { Expression of opinion and } \\
\text { saying no }\end{array}$ & $4.9 \pm 1.5$ & $7.7 \pm 1.7$ & 2.8 & 9.2 & $<0.001^{* *}$ \\
\hline Submission and avoidance & $2.3 \pm 2.1$ & $3.7 \pm 1.1$ & 2.4 & 7.8 & $<0.001^{* *}$ \\
\hline $\begin{array}{l}\text { Initiation and expression of } \\
\text { feeling }\end{array}$ & $3.6 \pm 1.8$ & $6.4 \pm 1.6$ & 2.7 & 8.1 & $<0.001^{* *}$ \\
\hline Total assertiveness scale & $11.8 \pm 4.2$ & $20.4 \pm 4.2$ & 8.5 & 11.03 & $<0.001^{* *}$ \\
\hline
\end{tabular}




\section{Effect of Assertiveness Training Program on Psychiatric Mental Health Nurses'}

\section{Communication Skills and Self-esteem}

Table (5): Comparison between total mean scores changes of communication skills inventory among study group pre and post program implementation $(n=50)$.

\begin{tabular}{|l|c|c|c|l|l|}
\hline \multirow{2}{*}{$\begin{array}{l}\text { Communication skills } \\
\text { inventory }\end{array}$} & $\begin{array}{l}\text { Study group } \\
\text { Preprogram } \\
(\mathrm{n}=50)\end{array}$ & $\begin{array}{l}\text { Study group } \\
\text { Post program } \\
(\mathrm{n}=50)\end{array}$ & $\begin{array}{l}\text { Paired } \\
\text { difference }\end{array}$ & \multicolumn{2}{|l}{ Paired sample } \\
\cline { 2 - 7 } Mean \pm SD & Mean \pm SD & $\begin{array}{c}\text { Mean } \\
\text { difference }\end{array}$ & $\begin{array}{l}\text { T- } \\
\text { Test }\end{array}$ & P-value \\
\hline $\begin{array}{l}\text { Mental dimension } \\
\text { subscale }\end{array}$ & $33.4 \pm 4$ & $61.8 \pm 4$ & 28.4 & 14.3 & $<0.001 * *$ \\
\hline $\begin{array}{l}\text { Emotional dimension } \\
\text { subscale }\end{array}$ & $31.1 \pm 7.8$ & $60.4 \pm 11.4$ & 29.3 & 15.1 & $<0.001^{* *}$ \\
\hline $\begin{array}{l}\text { Behavioral dimension } \\
\text { subscale }\end{array}$ & $34.1 \pm 8.2$ & $59 \pm 12.7$ & 24.9 & 11.8 & $<0.001^{* *}$ \\
\hline $\begin{array}{l}\text { Total communication } \\
\text { skills inventory }\end{array}$ & $98.6 \pm 15.4$ & $181.3 \pm 36.02$ & 82.7 & 15.1 & $<0.001^{* *}$ \\
\hline
\end{tabular}

Table (6): Correlation between total self-esteem, assertiveness skills and communication skills among study group post program implementation $(\mathbf{n = 5 0})$

\begin{tabular}{|l|l|l|l|l|}
\hline \multirow{2}{*}{ Variables scales } & \multicolumn{4}{l}{ Post program implementation(n=50) } \\
\cline { 2 - 5 } & \multicolumn{2}{|l|}{ Total self-esteem } & $\begin{array}{l}\text { Total } \\
\text { skills }\end{array}$ & \multicolumn{2}{l|}{ assertiveness } \\
\cline { 2 - 5 } & $\mathbf{R}$ & p-value & $\mathbf{R}$ & p-value \\
\hline Total assertiveness skills & $\mathbf{0 . 6 8}$ & $<0.001 * *$ & - & - \\
\hline Total communication Skills & $\mathbf{0 . 9 2}$ & $<0.001 * *$ & $\mathbf{0 . 7 4}$ & $<0.001 * *$ \\
\hline
\end{tabular}

\section{Discussion}

Assertiveness training programs help the individual to self-actualize without abusing the rights of others. Therefore, it is more appropriate to assist psychiatric nurses to learn assertion skills through assertive training program. Previous researches on assertiveness training have supported that attainment of assertiveness skills has been linked to increased assertiveness, and selfesteem. Psychiatric nurses who have poor self-esteem and poor interpersonal skills without a doubt exhibit negative professional attitudes and behaviors (Kanade, 2019). So, this study aimed to assess the effect of assertiveness training program on psychiatric mental health nurses' communication skills and self-esteem.

The present study revealed that, nearly half of the studied sample their age ranged between 30 - 40 years with $\mathrm{M} \pm \mathrm{SD}$ (37.5 \pm 5.8 ). This result may be due to limited number of novice nurses (young age nurses) who employed in the psychiatric hospitals. This result is in agreement with El-Amrosy, 2015; \& Kanade, (2019), who found that more than half of studied nurses their age above 30 years old.

Regarding sex of the studied sample, the present study revealed that more than half were female. This may be due to the fact that females are the prominent gender in the 
nursing practice. This result is in agreement with Mohamed \& Abd El Hamed, (2016) who found that the majority of the studied nurses were females.

Regarding marital status, the present study found that more than two thirds of studied sample were married. This result may be due to most of studied nurses at the age group between 30-40years old, in these age most persons be in marriage. This result is in agreement with Abd El Gawad, (2007) who mentioned that the highest frequency of the studied nurses was married.

Regarding the educational level, the present study revealed that more than half of the studied sample had nursing diploma and two fifth of them graduated from technical institute. This result could be due to the fact that nursing diploma and technical institutes of nursing provide the health agencies with large numbers of graduated nurses than faculties of nursing. This result is in agreement with Abdelaziz et al., (2020) who stated that nearly half of the studied nurses had nursing diploma and more than one third of them had technical institute.

Concerning the residence, the present study revealed that more than three quarters of the studied sample were from rural inhabitant. This may be due to that the psychiatric hospital in Benha located in rural area. This result is in agreement with ElAmrosy, (2015) who stated that nearly two thirds of the studied nurses from rural area.

Concerning the occupation of the studied sample, the present study revealed that the majority of them worked as nurse. This result may be due to that nurses are the corner stone and the large segment of any hospital particularly the mental health hospitals. Also limited number of nursing supervisors in the hospital because every department has one supervisor. This result is in agreement with Nakamura \& Tanoue,
(2017) who stated that nearly two thirds of the studied group are staff nurses.

Concerning years of experience, less than half of studied sample had experience of 10 - 15 years, this may be due to that the majority of studied sample at the age group between 30-40 years old. This result is in agreement with Nakamura \& Tanoue, (2017) who mentioned that the average years of work experience of the studied nurses was 13 years.

Concerning the income of the studied group, the present study revealed that about three quarters had not enough income. This result may be due to a low salary of the government hospital and poor promotions in a nursing career in general and in the psychiatric field specifically followed by increasing life requirements. This result is congruent with Abdelaziz et al., (2020) who stated that the majority of studied sample have low income.

The findings of the current study revealed that the all sample not received training program about assertiveness or communication skills. This may be due to lack of in-service training programs, educational and staff development in psychiatric hospitals. This result is in agreement with Kanade, (2019) who found that most of the study sample had no training courses about communication skills, only less than one fifth of them attended training courses about communication skills.

Regarding total mean scores changes of self-esteem scale among studied sample pre and post program implementation, the current study indicated that there was a highly statistically significant differences between total mean scores of self-esteem among the studied sample pre and post program implementation. These findings may be due to training program has contributed to improve the self - esteem level of the mental health 


\section{Effect of Assertiveness Training Program on Psychiatric Mental Health Nurses' \\ Communication Skills and Self-esteem}

nurses, as inclusion at the training program for a group training activities and providing continuous feedback by participants that had a positive role in increasing their intention to participate actively, as the collective action in accordance with the sessions program that gives the participants the freedom, enthusiasm and openness to debate the collective, particularly the presence of a supportive atmosphere and the respect for the beliefs of the nurses and their ideas, as well as the interaction of the researcher with the latest requirements which may have appositive effectiveness in the level of self-esteem and raise the level of enthusiasm to attend more meetings containing topics and information pertaining to personal and behavioral reality.

This result is in agreement with Rulin, (2004), who found that self-esteem of the experimental group of the study were significantly improved in nursing and medical students after assertiveness training.

Regarding total mean scores changes of assertiveness skills among study sample pre and post program implementation, the present study revealed that a highly statistically significant differences between total mean score changes of assertiveness skills subscales among study group pre and post program implementation. Also, the study revealed that a highly statistically significant differences between total mean scores of assertiveness skills scale among study group pre and post program implementation. This may be due to the success of assertiveness training program in which the researcher use role play with mental health nurses through expression of opinion and saying no assertively, confronting criticism, expressing dissatisfaction, and know to make request assertively. Assist the mental health nurse to properly express their internal thoughts and feelings that they aren't express in the past, as well as provided opportunities for them to interact with each other, providing more opportunity to express relationships with others, provided positive feedback, and the researcher at the end of the training sessions encouraged nurses to review situations in order to apply assertiveness skills in the future.

Corresponding, this finding is congruent with a previous study conducted by ElAmrosy, (2015) who indicated that there were statistically significant differences between preprogram and post training program regarding assertiveness skills.

Regarding total mean scores changes of communication skills scores among study group pre and post program implementation, the present study indicated that there was a highly statistically significant differences between total mean scores changes of communication skills subscales scores among study group pre and post program implementation. Also, the study revealed that there was a highly statistically significant differences between total mean scores of communication skills among study group pre and post program implementation.

This result may be due to that completing the assertiveness training program was useful for mental health nurse to understand and differentiate the concept of assertive behavior from other behaviors and how to apply it practically that reflected in their communications with others. Also using methods for communication training program as role playing exercise, group discussion, videotapes demonstrations of key communication skills, exchange of experiences among nurses, discussion, found that during combination of practical and theoretical communication training for nurses promote nurse's post-training communication skills. 
This result is in agreement with Mohamed \& Abd El Hamed, (2016) who noticed that there was a highly statistical significant difference between before and after training program regarding practice communication skills. The present study revealed that there was a highly statistically significant positive correlation between total self-esteem and total assertiveness skills and total communication skills post program implementation. Also, the result illustrates that a highly statistically significant positive correlation between total assertiveness skills and total communication skills, which indicated increase in self-esteem will associate with increase in assertiveness and communication skills.

This positive correlation between assertiveness and self-esteem may be due to that the assertiveness is an essential component of self-esteem, so increasing assertiveness lead to increased self-esteem. Furthermore, the training of assertiveness is based on understanding that any nurse as a human being has a fundamental value and that certain rights accompany that fact. Such a deep sense of value and actual behavioral ability to preserve it seems to motivate nurse to be self-responsible and to accept themselves comfortably and this will be reflected in their assertive communication with others.

The previous result is in agreement with those of Akbari et al., (2012), and Maheshwari \& Gill, (2015), who carried out their study to examine the relationship of assertive behavior and self-esteem among nurses in India and found that there was statistically significant positive correlation between total scores of participants' assertiveness and self-esteem.

Regarding the positive correlation between total communication skills and total self-esteem, this result may be due to that communication skills are very much related to one's sense of self-esteem. A sense of self concept and esteem influence the degree of confidence and directly related to their way of communication. Self-esteem is one of the ways that we feel about ourselves, to which we value ourselves. Nurses who has low selfesteem will always be little themselves despite outward success. This result is in agreement with Ammentorp et al., (2007), who found that nurses who participated in the communication course improved their selfefficacy for specific communication tasks.

The positive correlation between total assertiveness skills and total communication skills may be due to that assertiveness for professional nursing is considered as a significant behavior to communicate successfully with clients, families and colleagues. Also this result is in agreement with Gultekin et al., (2018), found that there was difference between the pre-and postassertiveness education program in communication skills of the experimental group and the sub-dimension and total point averages was statistically significant.

\section{Conclusion:}

Assertiveness training program have a positive effect on communication skills and self-esteem of psychiatric mental health nurses.

\section{Recommendation:}

Provision of assertiveness training program to the nonassertive psychiatric nurses to promote their self-esteem and to improve their communication with colleagues, families and patients

- Workshops for nurses about communication skills and how to be a good communicator with the patients, families and staff.

- Periodical systematic assessment of psychiatric nurse's level of self-esteem, assertiveness. 


\section{References:}

Abd El Gawad, Z., Gad, El., Abd El, Kader E., \& Lachine, O. (2007). The effect of Assertive Training Techniques on Improving Coping Skills of Nurses in Psychiatric Set Up. ASNJ, 6, 57-74.

Abdelaziz, E., Diab, I., Ouda, M., Elsharkawy, N., \& Abdelkader, F. (2020). The effectiveness of assertiveness training program on psychological wellbeing and work engagement among novice psychiatric nurses. Nursing Forum and Independent Voice of Nursing, 55(3).

Ahmed, M. (2011). Assessment of the assertiveness and job satisfaction among high qualified nurses at Suez Canal University Hospitals Unpublished Master Thesis, Nursing Administration, Faculty of Nursing, Suez Canal University, Eygpt, pp.50, 64, $65 \& 81$.

Akbari, B., Mohamadi, J., \& Sadeghi, S. (2012). Effect of assertiveness training methods on self-esteem and general selfefficacy female students of Islamic Azad University, Anzali Branch. Journal of Basic and Applied Scientific Research; 2 (3).

Ammentorp, J., Kofoed, P., \& Mainz, J. (2007). The effect of training in communication skills on medical doctors' and nurses' self-efficacy. A randomized controlled trial. Patient Educ Couns. Patient Educ Couns, 66(3).

El- Amrosy, S. (2015). The Effect of Assertiveness Training Program on Improving Self-Esteem of Psychiatric Nurses. Journal of Nursing science, 1(1).

Ersanli, K., \& Balci, S. (1998). Developing a communication skills inventory: its validity and realibity. Turkish Psychological Counseling and Guidance Journal, 10(2), 712.
Ghareeb, G. A. (1986). Assertiveness Scale: Standardized Adapted Arabic version. Faculty of Education Journal (El-Azhar University), 6, 172-182.

Gultekin, A., Ozdemir, A., \& Budak, F. (2018). The Effect of Assertiveness Education on Communication Skills Given to Nursing Students. International Journal of Caring Sciences, 11(1).

Kanade A. (2019). The effect of assertiveness training program on nurses. Indian J Psy Nsg. 15(2).

Maheshwari, K. \& Gill, K. (2015). Relationship of assertiveness and selfesteem among nurses. Int J Health Sci Res, $5(6)$.

Mohamed, N., \& Abd El Hamed, N. (2016): The effect of assertiveness training program on psychiatric nurses' communication skills and self-Esteem. Medical Journal of Cairo University, 84 (1).

Mushtaq, B. (2018). Assertiveness in Nursing. COJ Nurs Health Care, 3(3).

Nakamura, Y. \& Tanoue, H. (2017). Development and evaluation of a modified brief assertiveness training for nurses in the workplace: a single-group feasibility study. BMC Nursing, 16(29).

Rosenberg, M. (1965). Society and the adolescent self- image, Princeton, NJ, Princeton University Press.

Rulin, Y. (2004). Evaluation of an assertiveness training program on nursing and medical students' assertiveness, selfesteem, and interpersonal communication satisfaction. Nurse Educ Today. 24(8).

Sayed, H. (2018). Assertiveness and Absenteeism and their Relation to Career Development among Nursing Personnel. Egyptian Journal of Health Care, 3(8). 
Shrestha, S. (2019). Assertiveness and Selfesteem among Nursing Students of Manipal College of Medical Science of Pokhara, Nepal. Journal of Chitwan Medical College, 9(28).

Ulutasdemir, N. (2018). Nursing: Effective Communication in Nursing. $1^{\text {st }}$ edition. London. Intech Open.

Wolpe, J. \& Lazarus, A. (1966). Behavioral therapy techniques. New York. Capricorn.

World Health Organization. (2020). Global strategic directions for strengthening nursing and midwifery. Available at https//www.who.int. 
تأثير برنامج تدريبي لتوكيد الذات على مهارات التواصل وتقدير الذات لاي ممرضي الصحة النفسية

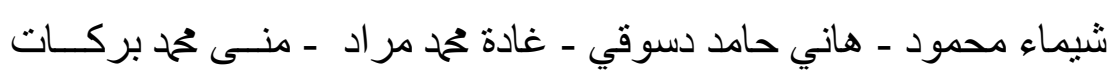

في اماكن الرعاية الصحية ، يركز توكيد الذات على قدرة الممرضات على توصيل آر ائهم واهتماماتهم

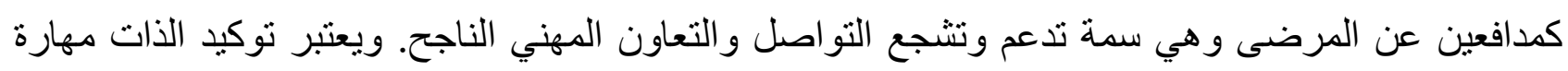

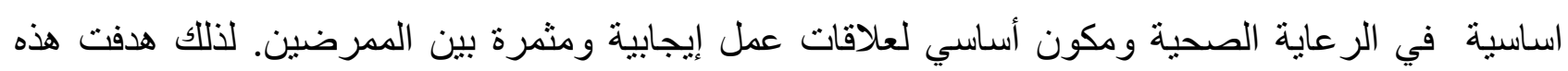

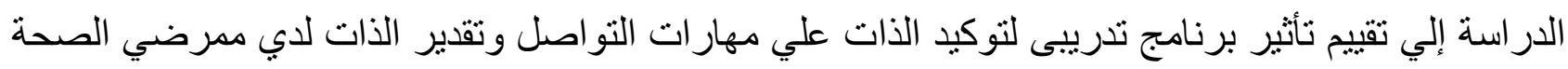
النفسية. وقد اجريت الدراسة في مستشفي الصحة النفسية في مدينة بنها، محافظة القليوبية التابعة للامانة العامة

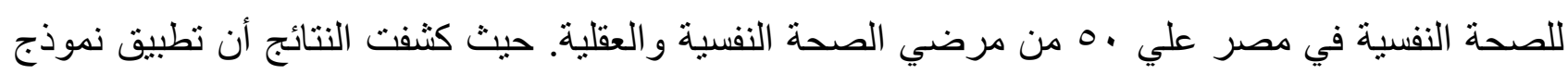

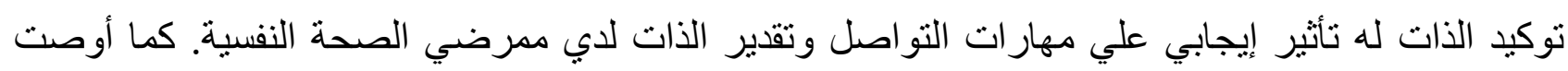
الدراسة بتعميم البرنامج التدريبي لتوكيد الذات لجميع ممرضي الصحة النفسية حديثي التخرج في جميع مستشفيات الأمر اض النفسية. 